\title{
PREDIKSI JUMLAH PENGUNJUNG PERPUSTAKAAN IAIN JEMBER DENGAN MENGGUNAKAN METODE FUZZY TIME SERIES
}

\author{
${ }^{1}$ Nurul Afifah, ${ }^{2}$ Nurul Aini, ${ }^{3}$ Mohammad Mukhlis \\ ${ }^{1}$ IAIN Jember, Jl. Mataram No.1 Mangli, (0331)487550 \\ ${ }^{2}$ IAIN Jember, Jl. Mataram No.1 Mangli, (0331)487550 \\ ${ }^{3}$ IAIN Jember, Jl. Mataram No.1 Mangli, (0331)487550 \\ e-mail: afifah15nurul@gmail.com
}

\begin{abstract}
Abstrak
Salah satu cara meningkatkan kualitas perpustakaan yakni dengan menambah dan memperbaiki fasilitas yang tersedia, dimana fasilitas tersebut dapat disesuaikan dengan jumlah pengunjung. Penelitian ini dilakukan guna mengetahui prediksi jumlah peningkatan pengunjung perpustakaan IAIN Jember di bulan yang sama pada tahun berikutnya. Data yang digunakan merupakan data jumlah pengunjung perpustakaan IAIN Jember pada Bulan Januari dan Februari di tahun 2020. Prediksi menggunakan metode Fuzzy Time Series dengan memproyeksikan data yang sudah ada untuk dibawa kedalam bentuk himpunan fuzzy dengan interval-interval yang ditentukan juga dalam bentuk data linguistik, yang kemudian dilakukan defuzzyfikasi untuk mengkomparasi hasil prediksi pada data linguistik yang digunakan. Setelah mendapatkan hasil prediksi dicari nilai AFER untuk memperkirakan nilai kesalahan dalam prediksi ini. Didapatkan hasil prediksi jumlah pengunjung perpustakaan di Bulan Januari dari minggu ke-1 sampai ke-4 diprediksi mencapai 429,50. Sedangkan pada Bulan Februari minggu ke-1 diprediksi mencapai 592,75 dan pada minggu ke-4 sebanyak 674,38.
\end{abstract}

Kata Kunci: Perpustakaan, Peramalan, Fuzzy time series

\section{PENDAHULUAN}

Sebagai salah satu tempat penyedia informasi dengan berbagai literatur, keberadaan perpustakaan menjadi sangat penting terutama pada tingkat perguruan tinggi. Perpustakaan perguruan tinggi sendiri, merupakan unit pelaksana teknis dengan menghimpun, memilih, mengelola, merawat serta melayani civitas akademik terkait sumber informasi. Sebagaimana tertera dalam Undang-undang No. 43 Tahun 2007 tentang perpustakaan dalam pasal 1, disebutkan bahwa Perpustakaan sebagai institusi pengelola koleksi karya tulis, karya cetak, dan/atau karya rekam secara profesional dengan sistem yang baku guna memenuhi kebutuhan pendidikan, penelitian, pelestarian, informasi dan rekereasi para pemustaka(Yusnimar, 2014).

Dengan fungsi perpustakaan yang sangat penting maka, perpustakaan harus memiliki kualifikasi dan juga kompetensi tertentu termasuk juga tersedianya pengelola perpustakaan yang berkualitas. Melihat tiap tahunnya mahasiswa IAIN Jember terus mengalami peningkatan, sudah semestinya Perpustakaan IAIN Jember juga terus berupaya memperbaiki dan menyediakan pelayanan semaksimal mungkin.

Permasalahan yang kerap kali dikeluhkan oleh mahasiswa adalah terkait dengan sejumlah fasilitas di perpustakaan yang dirasa jumlahnya kurang jika dibanding dengan jumlah 
mahasiswa. Beberapa permasalahan yang dapat dicari solusinya berdasarkan keluhan mahasiswa adalah terkait perbaikan pelayanan dan fasilitas pada penyediaan jumlah buku yang mencukupi, penambahan fasilitas ruang baca untuk memberi kenyamanan, juga penambahan unit komputer untuk peminjaman buku. Permasalahan-permasalahan tersebut tentunya berkaitan dengan jumlah pengunjung perpustakaan pada tiap harinya dan tentu tiap tahun yang terus bertambah. Oleh sebab itu peramalan pengunjung Perpustakaan IAIN Jember ini perlu dilakukan untuk membantu perbaikan pelayanan perpustakaan demi mencukupi fasilitas yang ada. Prediksi pengunjung perpustakaan ini dapat dilakukan dengan menggunakan salah satu metode Fuzzy, yakni Fuzzy time series yang menggunakan data-data lama sebagai acuan untuk prediksi.

Adapun masalah yang akan diteliti oleh penulis yaitu tentang berapakah prediksi jumlah pengunjung Perpustakaan IAIN Jember pada Bulan Januari dan Februari di tahun berikutnya? Tujuan dari penelitian yang penulis lakukan adalah melihat dan memprediksi jumlah pengunjung perpustakaan IAIN Jember pada bulan yang sama ditahun berikutnya, dengan pemodelan yang digunakan pada metode Fuzzy Time Series. Penelitian dengan metode Fuzzy Time Series pada prediksi jumlah pengunjung perpustakaan ini diharapkan dapat dijadikan rujukan atau pertimbangan oleh pihak pengelola perpustakaan IAIN Jember demi peningkatan pelayanan pada civitas akademisi.

The purpose of time series analysis is generally twofold: to understand or model the stochastic mechanism the gives rise to an observed series and to predict or forecast the future values of a series based on the history of that series and, possibly, other related series or factor(Cryer, Chan, 2008: 1). Berdasarkan buku Time Series karya Cryer dan Chan, dijelaskan bahwa dari pemodelan deret waktu atau Time Series kita dapat memahami dan memodelkan mekanisme stokastik dan memunculkan seri yang diamati serta memprediksi atau memperkirakan nilai-nilai masa depan berdasarkan sejarah dari seri tersebut dan mungkin terkait dengan lainnya. Metode time series diyakini memiliki pengulangan pola dari masa lampau pada masa sekarang. Metode ini digunakan untuk memproyeksikan data yang akan datang.

Logika fuzzy pertama kali dikembangkan oleh Lotfi A. Zadeh pada tahun 1965. Logika fuzzy adalah metode yang dasarnya dari sistem kecerdasan buatan (Artificial Intelligence) yang dapat menirukan kemampuan manusia dalam berfikir ke dalam bentuk algoritma yang 
kemudian dijalankan oleh mesin. Dalam jurnal Pengembangan Teknologi Informasi dan Ilmu Komputer (2017) yang berjudul "Peramalan Jumlah Kunjungan Wisatawan Kota Batu Menggunakan Metode Time Invariant Fuzzy Time Series”.

Fuzzy time series merupakan sebuah konsep baru yang diperkenalkan oleh Song dan Chissom pada tahun 1993, berdasarkan teori fuzzy set dan konsep variabel linguistic oleh Zadeh. Fuzzy time series menggunakan nilai-nilai linguistik pada peramalan, data historis tidak menggunakan nilai-nilai real namun berupa data linguistik. Pada tahun 1996 Chen memperkenalkan metode fuzzy time series menggunakan operasi aritmatika. Himpunan fuzzy merupakan suatu kelas bilangan dengan batasan yang samar, jika $U$ adalah himpunan semesta; $U=\left\{u_{1}, u_{2}, \ldots, u_{n}\right\}$, maka suatu himpunan fuzzy $A_{i}$, dari $U$ didefinisikan sebagai:

$A_{i}=\frac{u_{A i}\left(u_{1}\right)}{u_{1}}+\frac{u_{A i}\left(u_{2}\right)}{u_{2}}+\cdots+\frac{u_{A i}\left(u_{n}\right)}{u_{n}}$ dimana A adalah fungsi keanggotaan dari himpunan fuzzy $A_{i}$ dan $u_{A i}\left(u_{i}\right)$ adalah derajat keanggotaan dari $u_{i} \operatorname{ke} A_{i}$ dimana $u_{A i}\left(u_{i}\right)=[0,1]$ dan $1 \leq i \leq p$ Nilai derajat keanggotaan dari $u_{A i}\left(u_{i}\right)$ ditentukan berdasarkan aturan seperti di bawah ini:

Aturan 1: Jika data historis $X_{t}$ termasuk dalam $u_{i}$, maka nilai derajat keanggotaan untuk $u_{i}$ adalah 1 , dan $u_{i}+$ adalah 0,5 dan jika bukan $u_{i}$ dan $u_{i}+$ berarti dinyatakan 0 .

Aturan 2: Jika data historis $X_{t}$ termasuk dalam $u_{i}, 1 \leq \mathrm{i} \leq \mathrm{p}$ maka nilai derajat keanggotaan untuk $u_{i}$ adalah 1 , untuk $u_{i}-1$ dan $u_{i}+1$ adalah 0,5 dan jika bukan $u_{i}, u_{i}-1$ dan $u_{i}+$ 1 berarti dinyatakan 0 .

Aturan 3: Jika data historis $X_{t}$ termasuk dalam $u_{p}$, maka nilai derajat keanggotaan untuk $u_{p}$ adalah 1 , untuk $u_{p}-1$ adalah 0,5 dan jika bukan $u_{p}$ dan $u_{p}-1$, berarti dinyatakan 0 .

\section{METODE PENELITIAN}

Langkah-langkah yang digunakan dalam prediksi pengunjung perpustakaan dengan metode fuzzy time series adalah, sebagai berikut:

1. Mendefinisikan himpunan semesta

$U=\left[D_{\text {min }}, D_{\text {max }}\right]$ dengan $U$ didefinisikan sebagai himpunan semesta, sedangkan $D_{\text {min }}$ merupakan nilai terkecil dari data historis dan $D_{\max }$ merupakan nilai terbesar dari data historis.

2. Menentukan Jumlah dan Lebar Interval

Kemudian menentukan jumlah dan lebar interval. Jumlah interval menggunakan aturan Struges: $K=1+(3.3 \times \log (N))$ dimana $\mathrm{K}$ adalah jumlah kelas interval dan $\mathrm{N}$ adalah jumlah data historis. Jumlah interval harus dalam bentuk bilangan bulat. Setelah jumlah 
interval didapatkan maka selanjutnya ditentukan lebar interval dengan jumlah interval yang sama melalui rumus:

$$
\text { Lebar interval }=\frac{D_{\max }-D_{\min }}{\text { Jumlah interval }}
$$

Setelah itu membagi data dalam interval $u_{1}, u_{2}, \ldots, u_{n}$ dengan panjang yang sama.

3. Mendefinisikan Himpunan fuzzy

Untuk menyederhanakan, nilai keanggotaan dari himpunan fuzzy $A_{i}$ berada di antara 0 , $0.5,1$ dimana $1 \leq i \leq n$ dimana $\mathrm{n}$ adalah jumlah interval yang telah dibagi sebelumnya. Asumsikan variabal lingustik dari seilisih, yang akan digunakan untuk nilai linguistik himpunan fuzzy, misalnya didefinisikan $A_{1}$ (turun), $A_{2}$ (tetap), $A_{3}$ (naik). Pada langkah inilah ditentukan nilai linguistic pada tiap himpunan fuzzy (fuzzyfikasi).

4. Menentukan Fuzzy Logical Relationship

Fuzzy logical relationship ditentukan berdasarkan nilai $A_{i}$ yang telah ditentukan pada langkah sebeblumnya, yakni berdasarkan hasil fuzzyfikasi. Jika variable time series $F(t-1)$ difuzzyfikasi sebagai $A_{i}$ dan $F(t)$ sebagai $A_{j}$, maka $A_{i}$ berelasi $A_{j}$ yang dapat dinyatakan dengan notasi $A_{i} \rightarrow A_{j}$.

5. Fuzzy Logic Relationship Group

Dari hasil fuzzy logic relationship selanjutnya akan dibentuk fuzzy logical relationship group.

6. Defuzzyfikasi

Berdasarkan hasil dari fuzzy logical relationship group. Selanjutnya adalah proses defuzzyfikasi serta perhitungan prediksi. Cara perhitungannya adalah pada fuzzy logical relationship group ditentukan bahwa, misalkan $A_{1}, A_{2}$ sehingga $A_{1}$ nilai tengah dari $U_{1}$ dan $A_{2}$ adalah nilai tengah $U_{2}$, kemudian keduanya dijumlahkan dan dibagi dengan banyaknya jumlah relasi.

7. Ekstraksi Data Prediksi

Setelah didapatkan hasil prediksi, kemudian mengembalikan hasil prediksi berdasarkan fuzzyfikasi.

8. Hasil Kesalahan Menggunakan AFER

Setiap teknik peramalan atau prediksi tidak selalu mendapatkan hasil yang tepat, sebab sifat dari hasil prediksi belum tentu sesuai dengan sifat data sebenarnya. Oleh karena itu metode AFER atau Average Forecasting Error Rate digunakan untuk mengetahui besarnya kesalahan yang terjadi pada data hasil prediksi terhadap data actual atau data 
sebenarnya. Perhitungan AFER dalam jurnal Pengembangan Teknologi Informasi dan Ilmu Komputer (2017) yang berjudul "Peramalan Jumlah Kunjungan Wisatawan Kota Batu Menggunakan Metode Time Invariant Fuzzy Time Series” yakni:

$$
A F E R=\frac{\left(\frac{\left|A_{i}-F_{i}\right|}{A_{i}}\right)}{n} \times 100 \%
$$

\section{HASIL DAN PEMBAHASAN}

Sejumlah peneliti juga sempat melakukan riset mengenai prediksi pengunjung perpustakaan dengan metode-metode yang lain, sebagai contoh Tugas Akhir yang dilakukan Alfian Meilano Mahasiswa Jurusan Matematika Universitas Negeri Semarang dengan judul "Peramalan Jumlah Pengunjung Perpustakaan Daerah Provinsi Jawa Tengah dengan Menggunakan Metode Dekomposisi”. Maka pada penelitian kali ini metode yang digunakan adalah fuzzy time series. Penerapan metode fuzzy time series pada prediksi pengunjung perpustakaan dilakukan tahap-tahap sesuai dengan langkah-langkah prediksi. Penulis mengumpulkan data aktual jumlah pengunjung perpustakaan IAIN Jember dalam kurun waktu dua bulan, yang dapat dilihat sebagai berikut:

Tabel 1. Data historis: Bulan, Minggu ke-, Jumlah pengunjung

\begin{tabular}{|l|l|l|}
\hline \multicolumn{1}{|c|}{ Bulan } & \multicolumn{1}{c|}{ Minggu ke- } & \multicolumn{1}{c|}{ Jumlah Pengunjung Perpustakaan } \\
\hline Januari & 1 & 312 \\
\hline Januari & 2 & 319 \\
\hline Januari & 3 & 369 \\
\hline Januari & 4 & 344 \\
\hline Februari & 1 & 443 \\
\hline Februari & 3 & 103 \\
\hline Februari & 4 & 756 \\
\hline
\end{tabular}

Langkah 1. Berdasarkan tabel 1 kemudian ditentukan himpunan semesta yakni didapatkan nilai terkecil atau $D_{\min }$ adalah 103 dan $D_{\max }$ adalah 756, maka diperoleh $U=[103,756]$

Langkah 2. Selanjutnya ditentukan jumlah interval, sebagai berikut:

$$
K=1+(3.3 \times \log (7))
$$




$$
K=3,79 \approx 4
$$

Didapatkan jumlah interval adalah 4, selanjutnya menentukan lebar interval, sebagai berikut:

$$
\begin{gathered}
\text { Lebar interval }=\frac{756-103}{4} \\
\text { Lebar interval }=163,25
\end{gathered}
$$

Maka diperoleh pembagian interval:

$$
\begin{aligned}
& U 1=[103, \quad 266,25] \\
& U 2=[266,25, \quad 429,5] \\
& U 3=[429,5,592,75] \\
& U 4=[592,75, \quad 756]
\end{aligned}
$$

Langkah 3. Berikutnya mendefinisikan himpunan fuzzy.

Tabel 2. Matriks dari himpunan fuzzy

\begin{tabular}{|l|l|l|l|l|}
\hline$A_{i j}$ & \multicolumn{1}{|c|}{$A_{1 i}$} & \multicolumn{1}{|c|}{$A_{2 i}$} & \multicolumn{1}{c|}{$A_{3 i}$} & \multicolumn{1}{c|}{$A_{4 i}$} \\
\hline$A_{1 j}$ & 1 & 0,5 & 0 & 0 \\
\hline$A_{2 j}$ & 0,5 & 1 & 0,5 & 0 \\
\hline$A_{3 j}$ & 0 & 0,5 & 1 & 0,5 \\
\hline$A_{4 j}$ & 0 & 0 & 0,5 & 1 \\
\hline
\end{tabular}

Dari tabel 2 menghasilkan himpunan fuzzy sebagai berikut:

$A_{1}=\frac{1}{U_{1}}+\frac{0,5}{U_{2}}+\frac{0}{U_{3}}+\frac{0}{U_{4}}$

$A_{2}=\frac{0,5}{U_{1}}+\frac{1}{U_{2}}+\frac{0,5}{U_{3}}+\frac{0}{U_{4}}$

$A_{1}=\frac{0}{U_{1}}+\frac{0,5}{U_{2}}+\frac{1}{U_{3}}+\frac{0,5}{U_{4}}$

$A_{1}=\frac{0}{U_{1}}+\frac{0}{U_{2}}+\frac{0,5}{U_{3}}+\frac{1}{U_{4}}$

\section{Langkah 4. Penentuan fuzzy logical relationship}


Tabel 3. fuzzy logical relationship

\begin{tabular}{|l|l|l|c|c|}
\hline \multicolumn{1}{|c|}{ Bulan } & Minggu ke- & $\begin{array}{c}\text { Jumlah Pengunjung } \\
\text { Perpustakaan }\end{array}$ & Fuzzyfikasi & Relasi \\
\hline Januari & 1 & 312 & $A_{2}$ & $A_{1} \rightarrow A_{2}$ \\
\hline Januari & 2 & 319 & $A_{2}$ & $A_{1} \rightarrow A_{2}$ \\
\hline Januari & 3 & 369 & $A_{2}$ & $A_{1} \rightarrow A_{2}$ \\
\hline Januari & 4 & 344 & $A_{2}$ & $A_{1} \rightarrow A_{2}$ \\
\hline Februari & 1 & 443 & $A_{3}$ & $A_{2} \rightarrow A_{3}$ \\
\hline Februari & 3 & 103 & $A_{1}$ & - \\
\hline Februari & 4 & 756 & $A_{4}$ & $A_{4} \rightarrow A_{4}$ \\
\hline
\end{tabular}

Langkah 5. Selanjutnya menentukan fuzzy logic relationship group berdasarkan langkah 4

Tabel 4. Fuzzy logic relationship group

\begin{tabular}{|c|c|}
\hline Number of Group & Fuzzy logic relationship group \\
\hline 1 & $A_{1}, A_{2}$ \\
\hline 2 & $A_{2}, A_{3}$ \\
\hline 3 & $A_{3}, A_{4}$ \\
\hline 4 & $A_{4}$ \\
\hline
\end{tabular}

Langkah 6. Defuzzyfikasi, pada langkah ini akan ditentukan prediksi berdasarkan nilai tengah

Tabel 5. Defuzzyfikasi

\begin{tabular}{|c|c|l|c|}
\hline Number of Group & Fuzzy relationship Group & Perhitungan & Hasil prediksi \\
\hline 1 & $A_{1}, A_{2}$ & $(184,63+347,88) / 2$ & 266,25 \\
\hline 2 & $A_{2}, A_{3}$ & $(347,88+511,13) / 2$ & 429,50 \\
\hline 3 & $A_{3}, A_{4}$ & $(511,13+674,38) / 2$ & 592,75 \\
\hline 4 & $A_{4}$ & 674,38 & 674,38 \\
\hline
\end{tabular}

Hasil perhitungan pada tabel 5 yakni sebagai prediksi akan diekstrak pada data aktual, sehingga dapat dilihat dengan jelas peningkatan dari data aktual ke prediksi. Pada 
perhitungan, nilai $A_{1}$ didapatkan dari pengambilan nilai tengah berdasarkan $\mathrm{U} 1$, begitupun dengan $A_{2}$ yang didapatkan dari perhitungan nilai tengah $\mathrm{U} 2$, dan seterusnya pada nilai A yang lain.

Langkah 7. Ekstraksi data prediksi

Tabel 6. Ekstraksi data prediksi

\begin{tabular}{|l|l|l|c|c|}
\hline \multicolumn{1}{|c|}{ Bulan } & $\begin{array}{c}\text { Minggu } \\
\text { ke- }\end{array}$ & $\begin{array}{c}\text { Jumlah Pengunjung } \\
\text { Perpustakaan }\end{array}$ & Fuzzyfikasi & Prediksi \\
\hline Januari & 1 & 312 & $A_{2}$ & 429,50 \\
\hline Januari & 2 & 319 & $A_{2}$ & 429,50 \\
\hline Januari & 3 & 369 & $A_{2}$ & 429,50 \\
\hline Januari & 4 & 344 & $A_{2}$ & 429,50 \\
\hline Februari & 1 & 443 & $A_{3}$ & 592,75 \\
\hline Februari & 3 & 103 & - & - \\
\hline Februari & 4 & 756 & $A_{4}$ & 674,38 \\
\hline
\end{tabular}

Dari data pada tabel 6 diperoleh prediksi mingguan dalam dua bulan yakni, pada bulan Januari minggu ke-1 menjadi 429,50 dari yang awalnya berjumlah 312. Peningkatan dengan jumlah 429,50 tidak hanya pada bulan Januari minggu ke-1 saja, namun pada 4 minggu di bulan Januari hal ini dikarenakan jumlah pengunjung perpustakaan IAIN Jember pada data aktual di bulan Januari relatif stabil dan sama dengan jumlah sebanyak 300an orang.

Langkah 8. Perhitungan AFER pada setiap data prediksi yang dilakukan

Tabel 7. Perhitungan AFER

\begin{tabular}{|l|l|l|c|c|}
\hline \multicolumn{1}{|c|}{ Bulan } & \multicolumn{1}{c|}{$\begin{array}{c}\text { Minggu } \\
\text { ke- }\end{array}$} & $\begin{array}{c}\text { Jumlah } \\
\text { Pengunjung } \\
\text { Perpustakaan }\end{array}$ & Prediksi & AFER \\
\hline Januari & 1 & 312 & 429,50 & 0,0538 \\
\hline Januari & 2 & 319 & 429,50 & 0,0494 \\
\hline Januari & 3 & 369 & 429,50 & 0,0234 \\
\hline Januari & 4 & 344 & 429,50 & 0,0355 \\
\hline Februari & 1 & 443 & 592,75 & 0,0482 \\
\hline Februari & 3 & 103 & - & - \\
\hline Februari & 4 & 756 & 674,38 & 0,0154 \\
\hline & \multicolumn{2}{|c|}{ Rata-rata AFER } & 0,0376 \\
\hline
\end{tabular}

Berdasarkan tabel terakhir yakni tabel 7 dapat kita lihat bahwa AFER yang diperoleh pada prediksi ini relatif rendah dan mendekati 0. Pada bulan Februari minggu ke-4 terdapat nilai 
AFER paling rendah dengan nilai 0,0154 dan pada bulan Januari minggu ke-2 terdapat nilai AFER paling tinggi yakni 0,0494. Pada prediksi pengunjung perpustakaan IAIN Jember didapatkan nilai rata-rata AFER atau kesalahan sebesar 0,0376.

\section{SIMPULAN DAN SARAN}

Berdasarkan hasil analisis dan prediksi yang dilakukan, diperoleh perediksi jumlah pengunjung perpustakaan di Bulan Januari dari minggu ke-1 sampai ke-4 mencapai 429,50. Sedangkan pada Bulan Februari minggu ke-1 diprediksi mencapai 592,75 dan pada minggu ke-4 sebanyak 674,38. Dari prediksi menggunakan fuzzy time series ini juga menunjukan nilai kesalahan atau AFER dari data prediksi ke data aktual relatif rendah dengan rata-rata sebesar 0,0376. Maka tingkat prediksi menggunakan metode fuzzy time series ini dipastikan cukup efektif dan baik.

Saran yang dapat disampaikan oleh penulis untuk penelitian selanjutnya adalah agar pencarian data historis dari studi kasus lebih rinci dan lengkap lagi. Juga pada metode yang digunakan agar dapat dikombinasikan dengan metode yang lain sehingga lebih fariatif.

\section{DAFTAR PUSTAKA}

\section{Books:}

Cryer, Jonathan D., Chan, Kung-Sik. (2008). Time Series Analysis With Applications in R (2nd ed.). Lowa City: Springer Science+Business Media, LLC

Elfajar, A. B., Setiawan, B. D., \& Dewi, C. (2017). Peramalan Jumlah Kunjungan Wisatawan Kota Batu Menggunakan Metode Time Invariant Fuzzy Time Series. Jurnal Pengembangan Teknologi Informasi dan Ilmu Komputer e-ISSN, 2548, 964X.

Meilano, A. (2017). Peramalan Jumlah Pengunjung Perpustakaan Daerah Provinsi Jawa Tengah Dengan Menggunakan Metode Dekomposisi. Doctoral dissertation: Universitas Negeri Semarang.

Yusnimar, Y. (2014). E-book dan pengguna perpustakaan perguruan tinggi di Jakarta. $A L$ MAKTABAH, 13(1).

\section{Online journal:}

Jilani, T. A., \& Burney, S. M. A. (2008). A refined fuzzy time series model for stock market forecasting. Physica A: Statistical Mechanics and its Applications, 387(12), 2857-2862.

\footnotetext{
Prediksi Jumlah Pengunjung Perpustakaan IAIN Jember Dengan Menggunakan Metode Fuzzy Time 
Nugroho, K. (2016). Model Analisis Prediksi Menggunakan Metode Fuzzy Time Series. INFOKAM, 12(1).

Satria, I. M. C., Sukarsa, I. K. G., \& Jayanegara, K. Peramalan Jumlah Wisatawan Australia Yang Berkunjung Ke Bali Menggunakan Multivariat Fuzzy Time Series. E-Jurnal Matematika, 4(3), 90-97.

Wanayasa, I. G. N. A., Kencana, I. P. E. N., \& Nilakusumawati, D. P. E. (2012). Peramalan Produk Domestik Regional Bruto (PDRB) Provinsi Bali Dengan Menggunakan Metode Fuzzy Time Series. E-Jurnal Matematika.

Yuni, S., Talakua, M. W., \& Lesnussa, Y. A. (2015). Peramalan Jumlah Pengunjung Perpustakaan Universitas Pattimura Ambon Menggunakan Metode Dekomposisi. BAREKENG: Jurnal Ilmu Matematika dan Terapan, 9(1), 41-50.

\section{Theses, Dissertation:}

Putra, N. A., Kurniawan, H., \& Ritha, N. (2016). Prediksi Jumlah Penduduk Menggunakan Fuzzy Time Series Model Chen (Studi Kasus: Kota TanjungPinang). In Seminar Nasional Matematika. 